\title{
Business process projection in relation to the internationalization of the external environment of industrial companies
}

\author{
Jan Váchal ${ }^{1, *}$, Petra Pártlová $^{1}$ and Jarmila Straková ${ }^{1}$ \\ ${ }^{1}$ The Institute of Technology and Business, Okružní 517/10, 37001 České Budějovice, Czech \\ Republic
}

\begin{abstract}
Highly intensive internalization of the world economy requires the business sector to have different view of strategic management and decision making, together with the quality and content of business processes. Changes in the environment of enterprises significantly influence their function and behaviour, causing a need to significantly change enterprise architecture, including the design of development strategies. The paper focuses on analysing the processes of industrial enterprises, dealing with their importance and profit, classified by size. The result revealed that process activities, such as input logistics and marketing, are dominant in micro-enterprises, and such activities are important in profitable enterprises. In middle-sized enterprises, there is a more significant difference between marketing/sales and services without any relations to profit. However, there is a requirement to intensify these activities in non-profitable enterprises. Large enterprises revealed a significant influence of the scientific and technological development and also, to a lesser extent, of marketing, sales and purchase. Non-profitable enterprises should also focus on improving the quality of such processes.

Key words: internationalization, enterprises, business process, business environment
\end{abstract}

\section{Introduction}

Internationalizing the world economy in the age of its regionalism and realignment exerts intense pressures and actions which have a profound impact on business environments and their conduct. The business environment, in the manufacturing and industry sector, in particular, is subject to constant changes. These systematic changes require continual and recurrent theoretical examination of the corporate growth, carried out by many authors. Dagnino, King and Tienari [1] defined the human capital, strategy, management of human resources, innovation and skills as five main factors of the significant growth. This process is supported by the fact that companies work in conditions of discontinual and turbulent environment $[2,3]$, i.e. unpredictable, volatile and disconnected environment [4]. Thus, the strategic management constitutes a central organ of the organization management within the dynamic and competition environment. The strategic management consists of three

\footnotetext{
* Corresponding author: vachal@mail.vstecb.cz
} 
processes, such as strategic planning, strategy implementation and strategic control [5]. The most evident trends influencing business environment, processing and implementation of business strategy are suggested in literature [3, 6-12]. As a matter of fact, a good and flexible decision-making, speeding up information flows and effective use of modern information technologies are the key requirements for a successful modern company management [13]. In addition, activities and strategies of international companies (multinational enterprises, MNE) are more global than a perspective of the regional strategy shows $[14,15]$. Hence, a further research should suggest a detailed comparison of MNE approach towards the strategy on different levels (National, regional and global), based on the value chain. Works which claim that a business strategy does not depend on the ability to predict changes [16, 17] present a development milestone in projecting and implementing business strategies in conditions of the new economy. Moreover, a wide vision of potential customers and their needs within following three to five years is essential. The literature also notes that a thorough analysis is of a crucial importance. Therefore, there is not a sound reason to draw up a business strategy in advance. It may last a couple of years to find a really good strategy. Porter's model of five powers constitutes one of the basic pillars of the functional strategy, i.e. an essential characteristic of five competitive powers, their mutual configuration and a value chain analysis, including branches and value chain adapted to the requirements of a particular enterprise [18]. One of the premises of successful managerial strategic decision-making is a strategic situational analysis [19], which means the evaluation of factors of business environment, i.e. changes in customers' requirements, competitors, suppliers and development of macroeconomic factors including characteristics of internal enterprise resources. Similar definitions of situational analysis with only small differences in the descriptions of micro environment, mid-environment and macro-environment are suggested by a number of authors [20-29]. A strategic situational analysis means a complex approach to capture important factors influencing business activities in their mutual relations. Sedláčková [30] emphasizes the important role of the SA in strategic planning and decision-making at the top level of management. Furthermore, she points out individual strategic methods of the business environment and its internal resources, which play an important role in the business potential. Dedouchová $[31,32]$ in her works focuses on strategic analyses, shows relations between a strategy, organizational structure and business management system and deals with the conflicts of interests within their production and implementation. Companies often present themselves as socially responsible. Actions proving their social engagement are not confined only to the society in which companies exist, but they also achieve a huge impact on a wider environment $[33,34]$. The social responsibility of companies (corporate social responsibility, CSR) is often associated with a managers' effort to foster and maintain good relationships with the interested parties (employees, suppliers, bankers etc.). From this point of view, the social responsibility constitutes a very important component of the business strategy. The SA is also defined as a means for projecting a business strategy based on realizing its inner potential, possibilities and limits of a further development upon considering the impact of mid-environment and external environment $[13,14]$. Studying the available literature, we may accept the assumption that using analytical methods is highly effective in the frame of strategic business management, or more precisely, formulating a viable strategy; however, their structure and content should be considered since some of them do not have a universal character, and therefore they cannot be applied in a unified way. Follow-up analyses should be used as a support means for creating a companywide strategy. 


\section{Methods}

The research was based on a wide-range questionnaire survey of the business sector in the Czech Republic. The survey is still carried out. The results as presented in the paper include a sample of 176 enterprises, $70 \%$ of which are profitable. Of the total, there were 74 microenterprises, 70 small enterprises and 32 medium-sized enterprises. The size structure of the sample corresponds to the SME structure in the Czech Republic. In order to analyse the research questions, such enterprises that did not answer or the answers were unreliable due to a link to follow-up question were left out of the sample. The statistics used Fisher's exact test and a two-sample test. The two-sample test revealed the p-value and two-sided $95 \%$ interval estimate of ratio differences. For Fisher's test, p-value is reported as it is the test statistics itself. Both tests were carried out at the significance level of 0.05 . The research analysed questions related to testing the significance of business processes in terms of their significance for profitability classified by the size of the enterprises (micro-enterprises and small enterprises, medium-sized and large enterprises.

\section{Results and discussion}

\subsection{Micro enterprises and small enterprises}

In regard to a small number of enterprises in the micro-enterprise group, micro-enterprises and small enterprises were grouped together.

Table 1. Processes in micro-enterprises and small enterprises and their impact on profitability (in \%)

\begin{tabular}{|l|r|r|r|}
\hline \multicolumn{1}{|c|}{ Process } & \multicolumn{1}{c|}{$\begin{array}{c}\text { non- } \\
\text { profit }\end{array}$} & \multicolumn{1}{c|}{ profit } & \multicolumn{2}{c|}{$\begin{array}{c}\text { Difference profit }- \text { non- } \\
\text { profit }\end{array}$} \\
\hline Input logistics & 13.6 & 37.7 & 24.1 \\
\hline Production & 59.1 & 81.1 & 22.0 \\
\hline Output logistics & 13.6 & 32.1 & 18.4 \\
\hline Marketing and sale & 22.7 & 45.3 & 22.6 \\
\hline Basic and accompanying services & 18.2 & 32.1 & 13.9 \\
\hline Purchase & 31.8 & 32.1 & 0.3 \\
\hline $\begin{array}{l}\text { Scientific-technological } \\
\text { development }\end{array}$ & 0.0 & 5.7 & 5.7 \\
\hline Human resources management & 18.2 & 20.8 & 2.6 \\
\hline Enterprise infrastructure & 4.5 & 15.1 & 10.5 \\
\hline
\end{tabular}

Tested differences bigger than $10 \%$ are marked in bold. With the view of a large number of aggregates of profit and non-profit enterprises, results of the two-sample test on ratio differences are shown. Significant differences are marked in bold. 


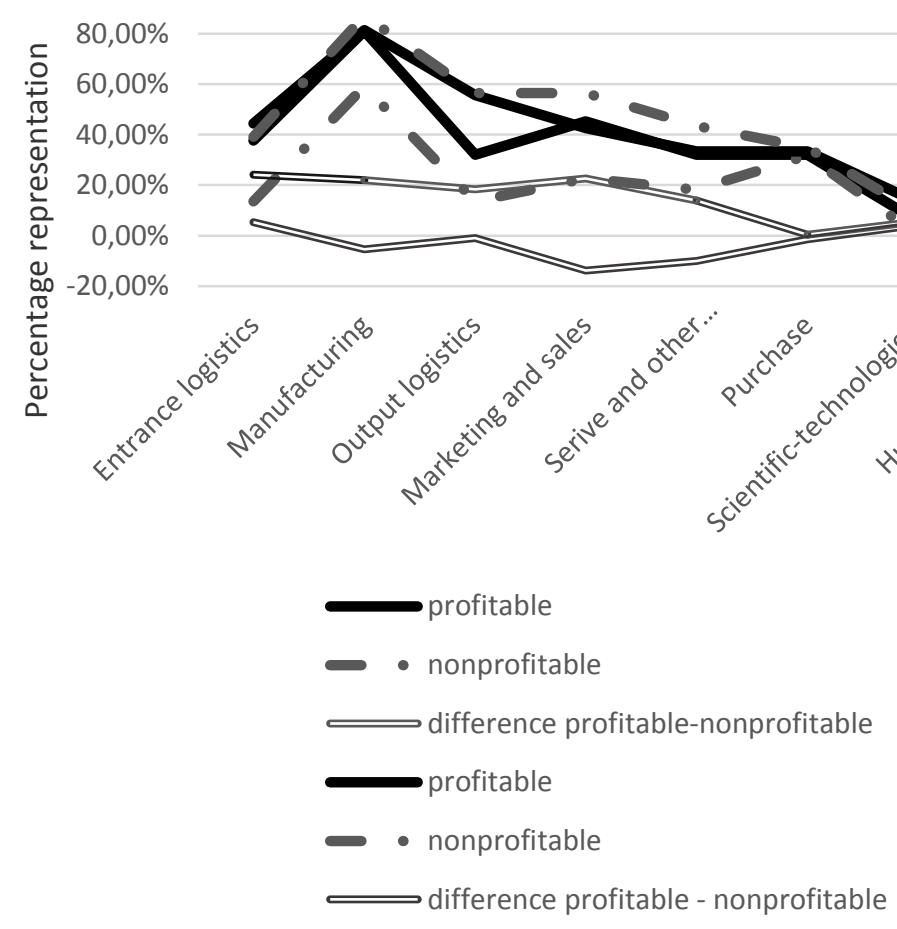

Figure 1. Processes in micro-enterprises and small enterprises and their impact on profitability

Table 2. Testing individual processes in regard to their significance and impact on profitability

\begin{tabular}{|l|r|r|r|}
\hline \multicolumn{1}{|c|}{ Process } & \multicolumn{1}{c|}{$\begin{array}{c}\text { Testing } \\
\text { statistics }\end{array}$} & \multicolumn{1}{c|}{ P-value } & $\begin{array}{c}\text { Interval estimate of the ratio } \\
\text { difference }\end{array}$ \\
\hline Input logistics & 2.436 & 0.0148 & $(0.047 ; 0.435)$ \\
\hline $\begin{array}{l}\text { Manufacturing } \\
\text { process }\end{array}$ & 1.871 & 0.061 & $(-0.010 ; 0.451)$ \\
\hline Output logistics & 1.895 & 0.058 & $(-0.006 ; 0.375)$ \\
\hline Marketing and sale & 2.005 & 0.045 & $(0.005 ; 0.446)$ \\
\hline $\begin{array}{l}\text { Basic and } \\
\text { accompanying } \\
\text { services }\end{array}$ & 1.332 & 0.183 & $(-0.065 ; 0.343)$ \\
\hline $\begin{array}{l}\text { Enterprise } \\
\text { infrastructure }\end{array}$ & 1.592 & 0.111 & $(-0.024 ; 0.235)$ \\
\hline
\end{tabular}

The results shown in the table indicate significant differences on the confidence level of $95 \%$ only in processes in the area of input logistics and marketing and sale. In this case, the ratio of profit enterprises, which focus on the process, is significantly higher than the non-profit ones. The test did not reveal any statistically significant ratio differences in other areas. P-value is only little higher than 0.05 level and interval estimates, of which the low limit is negative but very close to zero, indicating a very close result, which means that choosing only a little lower confidence level would show a difference. Therefore, profit enterprises show higher ration than the non-profitable. 


\subsection{Middle-sized enterprises}

Table 3. Processes in middle-sized enterprises and their impact on profitability (in \%)

\begin{tabular}{|l|r|r|r|}
\hline \multicolumn{1}{|c|}{ Process } & non-profit & profit & \multicolumn{2}{c|}{$\begin{array}{c}\text { Difference profit - non- } \\
\text { profit }\end{array}$} \\
\hline Input logistics & 39.1 & 44.4 & 5.3 \\
\hline Production & 87.0 & 81.5 & -5.5 \\
\hline Output logistics & 56.5 & 55.6 & -1.0 \\
\hline Marketing and sale & 56.5 & 42.6 & $\mathbf{- 1 3 . 9}$ \\
\hline Basic and accompanying services & 43.5 & 33.3 & $\mathbf{- 1 0 . 1}$ \\
\hline Purchase & 34.8 & 33.3 & -1.4 \\
\hline Scientific-technological development & 8.7 & 13.0 & 4.3 \\
\hline Human resources management & 17.4 & 18.5 & 1.1 \\
\hline Enterprise infrastructure & 13.0 & 16.7 & 3.6 \\
\hline
\end{tabular}

Tested differences bigger than $10 \%$ are marked in bold. With the view of a large aggregate number of profit and non-profit enterprises, results of the two-sample test on ratio differences are shown.

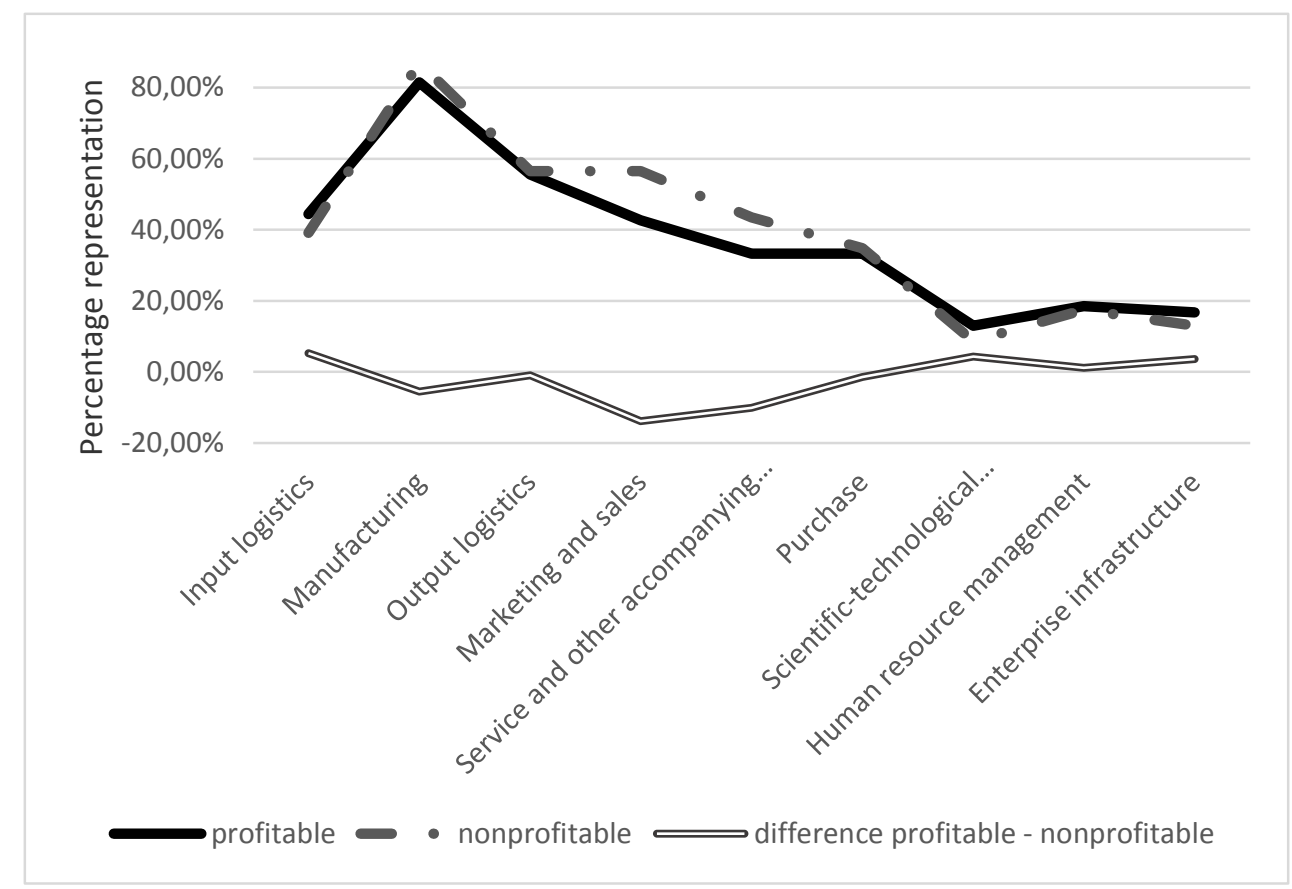

Figure 2. Processes in middle-sized enterprises and their impact on profitability 
Table 4. Testing of individual processes in regard to their significance and impact on profitability

\begin{tabular}{|l|r|r|r|}
\hline \multicolumn{1}{|c|}{ Process } & \multicolumn{1}{|c|}{$\begin{array}{c}\text { Testing } \\
\text { statistics }\end{array}$} & P-value & $\begin{array}{c}\text { Interval estimate } \\
\text { of the ratio } \\
\text { difference }\end{array}$ \\
\hline Marketing and sale & -1.129 & 0.259 & $(-0.381 ; 0.102)$ \\
\hline $\begin{array}{l}\text { Basic and accompanying } \\
\text { services }\end{array}$ & -0.834 & 0.404 & $(-0.340 ; 0.137)$ \\
\hline
\end{tabular}

A significant difference in the result of the group of medium-sized enterprises was indicated only in two cases, i.e. "Marketing and sale" and "Basic and accompanying services". Although the statistic test did not show any significant difference, even very convincingly ( $p$-values are multiplied higher than 0.05 level and interval estimates show zero, while extreme limits are far from zero), the opposite difference from the small enterprises is interesting, i.e. non-profit enterprises have a higher ratio of a central focus on these processes than the profitable ones (therefore, there are the negative ratio differences). It can, therefore, be assumed that non-profit enterprises feel the need to improve and enhance the activity of the aforementioned activity.

\subsection{Large enterprises}

Table 5. Processes in large enterprises and their impact on profitability (in \%)

\begin{tabular}{|l|r|r|r|}
\hline \multicolumn{1}{|c|}{ Process } & profit & non-profit & \multicolumn{2}{c|}{$\begin{array}{c}\text { Difference profit - non- } \\
\text { profit }\end{array}$} \\
\hline Input logistics & 52.6 & 36.4 & 16.3 \\
\hline Production & 86.8 & 81.8 & 5.0 \\
\hline Output logistics & 55.3 & 45.5 & 9.8 \\
\hline Marketing and sale & 57.9 & 27.3 & 30.6 \\
\hline Basic and accompanying services & 31.6 & 9.1 & 22.5 \\
\hline Purchase & 39.5 & 54.5 & -15.1 \\
\hline Scientific-technological development & 34.2 & 0.0 & 34.2 \\
\hline Human resources management & 39.5 & 27.3 & 12.2 \\
\hline Enterprise infrastructure & 18.4 & 27.3 & -8.9 \\
\hline
\end{tabular}

Tested differences bigger than $10 \%$ are highlighted in the table. In regard to the extent of the aggregate of non-profit enterprises, p-value of Fisher's exact test is suggested as the main result. The results of the two-sample test on the ratio difference and the interval estimate for this difference are given for guidance only. Statistically, significant differences are highlighted in the following tables. 


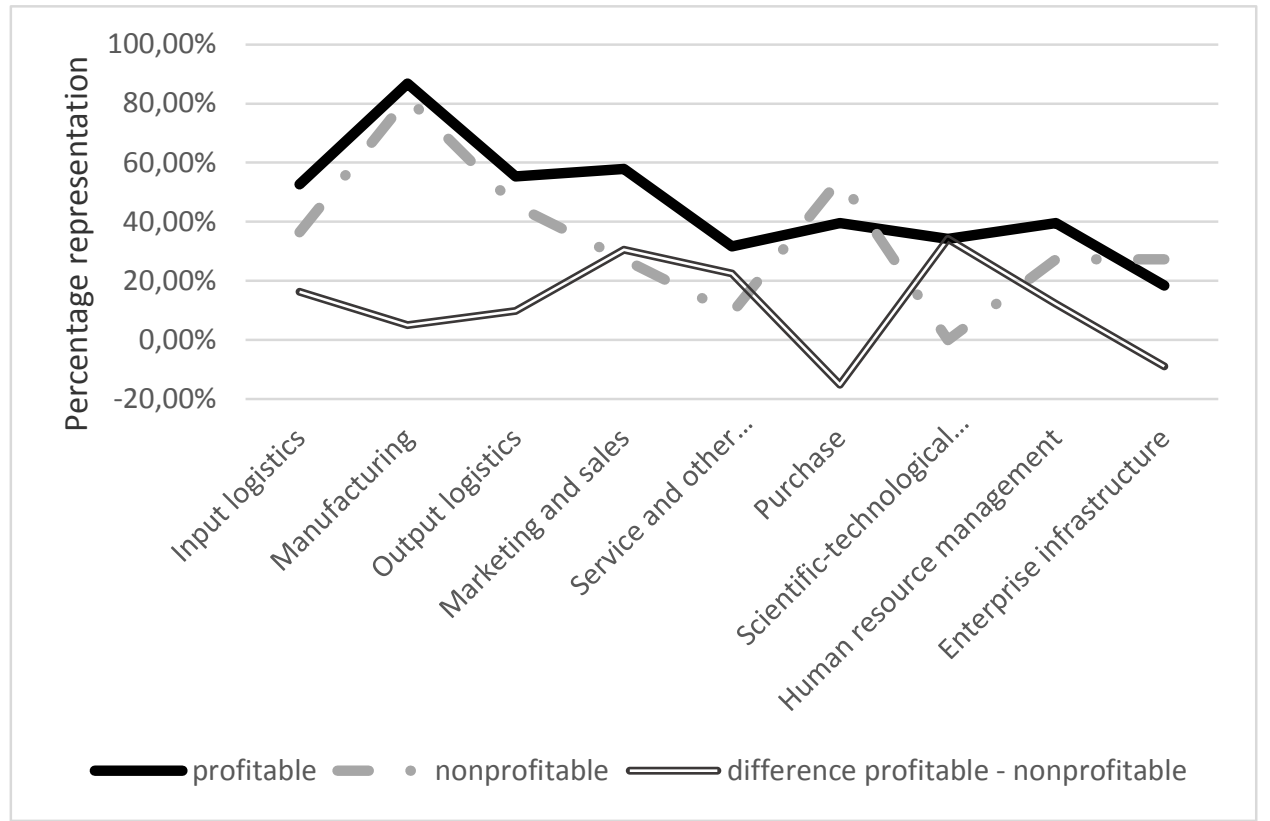

Figure 3. Processes in large enterprises and their impact on profitability

Table 6. Testing of individual processes in regard to their significance and impact on profitability

\begin{tabular}{|l|r|r|r|r|}
\hline \multirow{2}{*}{\multicolumn{1}{|c|}{ Process }} & \multirow{2}{*}{$\begin{array}{c}\text { P-value of } \\
\text { Fisher's } \\
\text { exact test }\end{array}$} & $\begin{array}{c}\text { Testing } \\
\text { statistics }\end{array}$ & P-value & $\begin{array}{c}\text { Two-sample test on ratio differences } \\
\text { Intestimate of } \\
\text { the ratio difference }\end{array}$ \\
\hline Input logistics & 0.496 & 0.979 & 0.327 & $(-0.163 ; 0.488)$ \\
\hline Marketing and sale & 0.095 & 1.959 & 0.0502 & $(-0.00023 ; 0.613)$ \\
\hline $\begin{array}{l}\text { Basic and } \\
\text { accompanying } \\
\text { services }\end{array}$ & 0.246 & 1.957 & 0.0503 & $(-0.00029 ; 0.450)$ \\
\hline Purchase & 0.493 & -0.887 & 0.375 & $(-0.483 ; 0.182)$ \\
\hline $\begin{array}{l}\text { Scientific- } \\
\text { technological } \\
\text { development }\end{array}$ & $\mathbf{0 . 0 2 4}$ & $\begin{array}{l}\text { Double-choice test on ratio differences was not } \\
\text { carried out as a result of zero frequency of non-profit } \\
\text { enterprises in the group. }\end{array}$ \\
\hline $\begin{array}{l}\text { Human resources } \\
\text { management }\end{array}$ & 0.724 & 0.782 & 0.433 & $(-0.184 ; 0.428)$ \\
\hline
\end{tabular}

In regard to the small number of non-profit enterprises, we cannot rely on the results of the two-sample test for ratio differences, it is necessary to take Fisher's Exact Test as a conclusion. The test in all areas showed a statistically significant difference between profit and non-profit enterprises, with a difference of more than $10 \%$, except in the field of scientific and technological development. There was a decisive influence in this area of the zero frequency in the group of non-profit enterprises. The marketing and sales situation was closest to the statistical significance.

Although the questionnaire finds a difference in ratio over $30 \%$, the test of significance was rejected. The tightness of the conclusion, however, indicates that this area is worth the attention as well as the area of purchase. Although the test did not prove the statistical 
significance of the difference, it shows that the ratio in non-profit enterprises is greater than in profitable enterprises.

\section{Conclusion}

The representation of processes in the business system on the general level depicts system framework for procedural business management; on the other hand, it introduces the corporate philosophy of the senior management. It is clear that senior management must take into account both the current competitive ring in the relevant sector and in the relevant size category and the prediction of the future development, regarding priorities and intensity.

The paper focused on these particular questions and outputs from the research can be summarized as follows.

Process significance in the area of "Input logistics" and "Marketing and sales" was analysed in micro-enterprises and small enterprises. The enterprises which prioritize these processes proved to be highly profitable.

The aggregate of middle-sized enterprises indicated a process significance only in two processes, i.e. "Marketing and sales" and "Basic and accompanying services. The fact that non-profit enterprises achieved a higher ratio of focusing on these processes than profitable is also interesting. It might be assumed that non-profit enterprises feel the need to improve and enhance the suggested activities, and profit enterprises consider these processes as sufficient and stable.

Large enterprises showed a dominant relation in "Scientific-technological development", which is in compliance with the expectation and commonly declared principles in business and management. The managers should also pay attention to the area of "Marketing and sales" and "Purchase". However even in this case, the same rules as in middle-sized enterprises are applied, i.e. business processes need improving.

Researchers consider these results only as the first entry to the system analysis of business processes. Apart from practical outcomes, valuable methodological experience has been gained; mainly in a view of the approach towards such burning and important issue as a projection of the process enterprise system.

\section{References}

1. G. B Dagnino, D. R. King, J. Tienari, The Strategic Management of Dynamic Growth. Long Range Planning, 50, 427-430 (2017)

2. P. F. Drucker, Driving in turbulent times [Ǩ́zení v turbulentní době]. Prague: Management Press (1994)

3. P. F. Drucker, Management challenges for the 21st century. New York: HarperBusiness (1999)

4. J. Truneček, Knowledge Management [Management znalostí]. Prague: C. H. Beck (2004)

5. Y. Salamzadeh, M. Y. Nia, M. R. Markovič, A. Salamzadeh, Strategic management development: the role of the learning) school in the promotion of the competence of managers. Economy and Society, 21, 1-23 (2016)

6. P. F. Drucker, Management: the future begins today [Management: budoucnost začiná dnes]. Prague: Management Press (1992)

7. P. F. Drucker, The Daily Drucker: 366 Days of Insight and Motivation for Getting The Right Things Done [Drucker na každý den: 366 zamyšlení a podnětů, jak dělat správné věci]. Prague: Management Press (2006) 
8. P. Kotler, Kotler on Marketing: How to Create and Control New Markets [Marketing podle Kotlera: jak vytváret a ovládnout nové trhy]. Prague: Management Press (2000)

9. Z. Pitra, Improving business performance [Zvyšování podnikatelské výkonnosti firmy]. Prague: Ekopress (2001)

10. J. Jirásek, Strategy: The Art of Business Victory [Strategie: uměni podnikatelských vitězství], 2.nd ed. Prague: Professional Publishing (2003)

11. F. Šmída, Strategies in Business Practice [Strategie v podnikové praxi]. Prague: Professional Publishing (2003)

12. Z. Souček, The 21st century company: we will overtake the best [Firma 21. stoleti: predstihneme nejlepši $]$. Prague: Professional publishing (2005)

13. J. Straková, J. Váchal, P. Pártlová, Strategic Management: Study Script [Strategický management: studijni skripta]. České Budějovice: The Institute of Technology and Business in České Budějovice [České Budějovice: Vysoká škola technická a ekonomická v Českých Budějovicích] (2017)

14. T. Blumentritt, W. Danis, Business strategy types and innovative practices. Journal of Management, 18, 274-291 (2006)

15. R. Mudambi, J. Puck, A Global Value Chain Analysis of the 'Regional Strategy' Perspective. Journal of Management Studies, 53, 1076-1093 (2016)

16. M. E. Porter, Recent Developments in Competitiveness and Strategy. Porter Prize Conference, Hitotsubashi University. Graduate School of International Corporate Strategy, Tokyo, Japan (2012)

17. M. E. Porter, Shared Value and Strategy. Shared Value Leadership Summit, New York (2015)

18. J. Magretta, Michael Porter clearly and comprehensibly [Michael Porter jasně a srozumitelně]. Prague: Management Press (2012)

19. M. Keřkovský, O. Vykypěl, Strategic Management: Theory for Practice [Strategické ř́zení: teorie pro praxi], 2.nd ed. Prague: C. H. Beck (2006)

20. J. Jakubíková, Strategic management [Strategický management]. Prague: Grada (2008)

21. M. Dedouchová, Business strategy [Strategie podniku]. Prague: C. H. Beck (2001)

22. T. Mallya, Fundamentals of Strategic Management and Decision Making [Základy strategického řizení a rozhodování]. Prague: Grada (2007)

23. M. Šulák, E. Vacík, Strategic management in enterprises and projects [Strategické rizzeni $v$ podnicich a projektech]. Prague: The university of finance and administration [Praha: Vysoká škola finanční a správní] (2005)

24. J.G. Frynas, K. Mellahi, Global strategic management, 2nd ed. New York: Oxford University Press (2011)

25. E. Kislingerová a kol., Business behavior in a globalizing environment [Chování podniku v globalizujicím se prostředí]. Prague: C. H. Beck (2005)

26. J. Veber, Environmental management [Environmentální management]. Prague: Oeconomica (2004)

27. E. Gomes, Mergers, acquisitions, and strategic alliances: understanding the process. New York: Palgrave Macmillan (2011)

28. E. Nigel, D. Campbell, Strategic management for travel and tourism. Repr. Oxford: Butterworth-Heinemann (2002) 
29. M. E. Porter, M. R. Kramer, Strategy and Society: The Link between Competitive Advantage and Corporate Social Responsibility. Harvard Business Review, 84 (2006)

30. H. Sedláčková, Strategic analysis [Strategická analýza]. Prague: C. H. Beck (2000)

31. M. Dedouchová, Business strategy: teaching texts for engineering studies [Strategie podniku: učebni texty pro inženýrské studium]. Prague: College of Economics [Praha: Vysoká škola ekonomická] (1995)

32. M. Dedouchová, PE412 - Enterprise Strategy [PE 412 - Strategie podniku]. Prague: C. H. Beck (2002)

33. J. Cox, Corporate social responsibility and social capital. Journal of Banking and Finance, 60, 252-270 (2015)

34. A. B. Carroll, K. M. Shabana, The Business Case for Corporate Social Responsibility: a review of concepts, research and practice. International Journal of Management Reviews, 12, 85-105 (2010) 